\title{
Optimization of Pangasius Catfish Production in Pagersari Village, Tulungagung Regency
}

\author{
Mochammad Fattah ${ }^{1 *}$, Susadiana ${ }^{2}$ and Dwi Sofiati ${ }^{3}$ \\ ${ }^{1}$ Faculty of Fisheries and Marine Sciences Universitas Brawijaya, Jl. Veteran 16 Ketawanggede, \\ Lowokwaru, Malang 65145, Indonesia \\ ${ }^{2}$ Fisheries Training and Counselling Center Banyuwangi, Jl. Raya Situbondo Km. 17, Parasputih, \\ Bangsring, Banyuwangi 68402, Indonesia \\ ${ }^{3}$ Study Program of Fisheries Socio-Economics PSDKU Universitas Brawijaya Kediri, Jl. Pringgodani, \\ Mrican, Mojoroto, Kediri 64111, Indonesia
}

*Correspondence :

mochammadfattah@ub.ac.id

Received : 2020-07-21

Accepted : 2020-12-03

Keywords :

Cultivation, Pangasius catfish, Optimal, Linear programming

\begin{abstract}
Pangasius catfish is freshwater fish for consumption that can be cultivated through fish farming. To produce optimal profits, Pangasius catfish farming must pay attention to the use of inputs in the form of seeds, feed, and electricity. The purpose of this study was to analyze the optimization of Pangasius catfish production in the Tondo Lestari fish cultivator group, Pagersari Village, Tulungagung Regency. Data collection techniques were in the form of interviews, observation and documentation. The data analysis used was linear programming using the POM-QM for Windows 5 software tool. The Pangasius catfish farming activities of the Tondo Lestari fish cultivator group have been optimal because they resulted in a low production difference between factual and optimal conditions of 3,05 $\mathrm{kg}$ or a profit of Rp. 10,502. The optimal production of Pangasius catfish in a pond size of $200 \mathrm{~m}^{2}$ was $3,173.21 \mathrm{~kg}$ and the optimal production in a pond size of $300 \mathrm{~m}^{2}$ was $4,839.83 \mathrm{~kg}$. Therefore, it can be concluded that Pokdakan Tondo Lestari can take advantage of additional feed and electricity input by reducing the use of seed input by 1.487 heads to increase profits.
\end{abstract}

\section{INTRODUCTION}

Freshwater fish for consumption that is widely cultivated is catfish (Pangasius sp.) (A'yunin et al., 2020). Pangasius catfish has been known in Indonesia since the 1970s, and its cultivation has developed until now (Meilisza, 2009). The highest demand for catfish in the domestic market is in Sumatra and Kalimantan, while the export market is in the United States and Europe (Darmawan et al., 2016). Tulungagung Regency is an Indonesian territory that cultivates catfish. According to Setyowati et al. (2017), the potential for inland fisheries spreading across 13 districts of Tulungagung Regency includes walking catfish (Clarias batrachus), gourami, and Pangasius catfish. These three types of fish were fed pellets with the harvest period per production cycle for gourami is 12 months, for Pangasius catfish is 6-7 months, and for walking catfish is $2.5-3$ months.

The Tulungagung Regency aquaculture pond in 2019 covered an area of 392.72 hectares with a total of 12,050 
cultivators who produced freshwater fish cultivation production of 39,073.78 tons per year (BPS, 2020). Pangasius catfish has been developed in Tulungagung since the 1990s (Yulisti and Putri, 2013). The production of Pangasius catfish in Tulungagung Regency on average is 15,000 tons per year with a total homebased fish farming (RTP) of 650. The Tondo Lestari Fish Cultivator Group (Pokdakan) is a group that operates three commodities in the cultivation of consumed fish, including walking catfish, Pangasius catfish, and gourami. In general, all group members have the technical expertise to cultivate the three existing commodities. The selection of commodities either of walking catfish, Pangasius catfish, or guramis depends on market prospects, selling prices, and operating costs in the form of manufactured pellet feed including price and quality/FCR, dynamic in each year or in each maintenance period. However, of the three commodity choices, Pangasius catfish is the main choice, or as the group's main commodity. The superiority of Pangasius catfish over the other two commodities is none other than the existence of a partnership system which greatly helps the group in terms of the availability of feed (pellets) to market certainty because there is a frozen fish fillet industry in the Tulungagung Regency.

The development of Pangasius catfish farming is influenced by water resources, land resources, feed, markets, and diseases (Rumimpunu et al., 2017). Growth is a parameter in fish farming to determine the production value of economic fish. Growth can be defined as an increase in length or weight over time (Manunggal et al., 2018). Feed is a production input in fish farming activities that affects the increase in Pangasius catfish production and supports the success of cultivation, but the largest production cost comes from feed costs (Poernomo et al., 2015). Meanwhile, every business has the goal of generating profits in order to ensure sustainability and productivity (Oladejo et al., 2019).

A parallel relationship between the limited amount of production and business capital is if the amount of capital of the cultivators is small, the amount of fish production produced is also small and vice versa. Apart from the amount of production and capital, cultivators have problems with the available input capacity. In solving those problems, optimization analysis can be carried out using linear programming (Wahyudy et al., 2016). Equality constraints can be solved by simple substitution methods and Lagrange multiplier method. Meanwhile, inequality constraints can be solved by using linear programming (Diatin et al., 2008). Linear programming is an optimization process using a decision model that can be formulated mathematically due to limitations in allocating resources (Hasmi, 2015). The purpose of this study was to analyze the optimization of Pangasius catfish production in the Tondo Lestari fish cultivator group in Tulungagung Regency.

\section{METHODOLOGY}

\section{Place and Time}

This research was conducted in July 2020 at Tondo Lestari Fish Cultivator Group in Tulungagung Regency, East Java.

\section{Research Design}

Data collection techniques used interviews, observation, and documentation. The data analysis on the optimization of the production of Pangasius catfish used POM-QM for Windows 5. The linear programming model (LP) implemented the two model formulations, namely the formulation of the objective function and the constraint function. The objective function in this study was formulated to determine the level of production from the use of optimal production factors so as to maximize profit with constraints in the form of the use of production factors or inputs which include 
all the inputs used in each cultivation pond and the non-negativity variable constraints (non-negative variables). The production factors that became the variables in this study were seeds, feed, and electricity.

\section{Work Procedures}

The model formulated must meet the assumptions of linear programming, namely: proportionality, additivity, divisibility, and certainty. According to Akpan and Iwok (2016), the objective function in linear programming can be used to maximize profit and minimize costs. Mathematically, this research is to maximize profit with the objective function, as follows:

$\mathrm{Z}_{\max }=\mathrm{C}_{1} \mathrm{X}_{1}+\mathrm{C}_{2} \mathrm{X}_{2}$

Meanwhile, the constraint function is as follows:

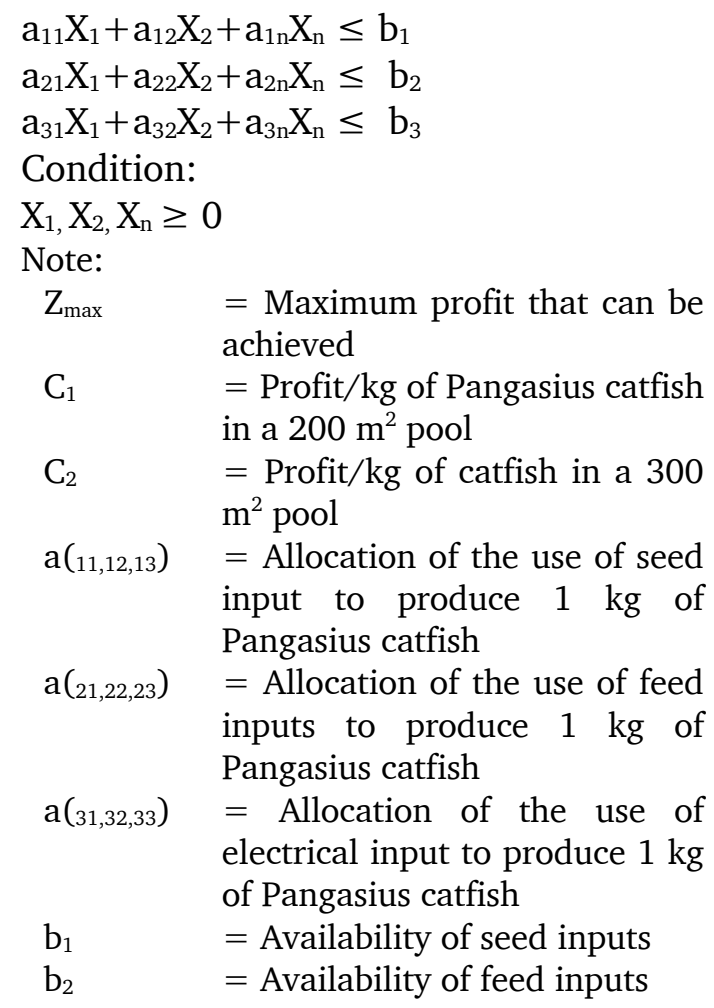

The optimal solution is a solution that meets the constraints of the problem and the goals that must be met (Yahya et al., 2012). Primal analysis was used to analyze the optimal combination of Pangasius catfish production that can be produced by Pokdakan by considering the limited resources owned by Pokdakan. Dual analysis was carried out to analyze resources that limited the objective function and resources that were overused as seen from the slack or surplus-value and the resulting dual value.

Sensitivity analysis was conducted due to uncertainty factors in fisheries production activities. This analysis applied the parameter of available resources to the lower bound and the upper bound, meaning that a solution was optimal if the parameter value was changed to be greater or lower.

\section{Data Analysis}

The data analysis on the optimization of the production of Pangasius catfish used POM-QM for Windows 5. The linear programming model (LP) implemented the two model formulations, namely the formulation of the objective function and the constraint function.

\section{RESULTS AND DISCUSSION The Cultivation of Pangasius catfish by Tondo Lestari Fish Cultivator Group}

The preparation of land or fish farming ponds consisted of three main activities, namely: cleaning the media/ cultivation pond, liming, and filling the cultivation media (pond water). The cleaning of the cultivation media was carried out after harvesting. The cleaning was done to clean the pond from the remaining dirt at the bottom of the pond after harvesting. Dirt at the bottom of the pond could be in the form of leftover fish food that was not eaten by fish and dirt that entered from outside the pond, such as leaves around the pond or other materials that entered the pond. Cleaning was also carried out on the pool walls by removing moss or dirt attached to the pool walls. Liming was done after the fish pond was cleaned or washed. It was done by covering the surface of the pond, the bottom and the walls of the pond with limestone with the aim of increasing water hardness and disinfection as well as $\mathrm{pH}$ adjustment. After lime coating was carried 
out on the surface of the pond, then the pond is left empty for two days.

Water resources are the main requirement for freshwater fish farming (Rumimpunu et al., 2017). Water filling was done after the pond liming process for two days. Water filling in the pool was carried out at a height of $120 \mathrm{~cm}$ or by adjusting the height of the pool construction. Afterward, the pond that had been fully filled was left for seven days. The composition of the water that entered or was filled into the pond was divided into two compositions/methods. The first composition was to fill the pond with new water from the water spring or groundwater. The second composition was to fill the pond with new water combined with existing water in other cultivation ponds with a ratio of 1 : 1 . The two media compositions would differentiate the gap between filling the water into the pond and stocking the seeds. The composition of the media consisting of new water from the water spring took seven days ( 1 week) before the seeds were added, while the composition of the media consisting of a mixture of old pond water with new water from the water spring (1:1) took a shorter time until the seeds were ready to be stocked, i.e., 3-4 days after water filling to the media, the fish seeds could be stocked. Fertilization activities were not carried out in this fish farming activity. As an alternative, a coating on the pond walls during liming and the use of old pond water, with the aim that planktons could be supplied from the old pond water, was carried out. The stocking of fish seeds was carried out after the cultivation media was completely ready, with the intermission adjusted to the composition of the water filled into the cultivation pond. The fish seeds that were stocked were Pangasius catfish seeds with a size of 5-6, or with a size ranging from 5 to $6 \mathrm{~cm}$. The time for stocking the fish seeds was in the morning when the water temperature was still stable. Fish seed stocking density was 20 fish $/ \mathrm{m}^{3}$.
Maintenance activities consisted of pond water observation, feeding and water draining. Moreover, water quality affects the growth and survival of water biota that is maintained (Putra et al., 2015). Therefore, the observation of pond water that should be carried out is the measurement of temperature, $\mathrm{pH}, \mathrm{DO}$ and other water quality parameters. However, the owner of the pool only observed the pool water visually of the color and smell of the water. Feeding was done twice a day, in the morning and evening since the fish seeds were first spread until the fish were 500-600 grams in size or 5-6 months of age. For fish with a size above 500 grams, feeding was done once a day, in the morning or afternoon. The third maintenance activity was water draining. Draining the water was carried out to maintain the quality of pond water and prevent disease attacks. Draining was done by removing and cleaning the dirt sediment at the bottom of the pond, while at the same time reducing the pool water by $3 / 4$ of the full water and adding new water. The time or intensity of pond water draining depended on the age of the fish after stocking the seeds, as follows: age of 2 months once, age 2-6 months once/month, age 6-7 months once/14 days, and age of 7-8 months once/7 days. Harvesting activities were carried out after the fish reached a size of 700 grams. The maintenance age range was 8 months after stocking the fish seeds.

\section{Optimization of Pangasius catfish Cultivation by Tondo Lestari Fish Cultivator Group}

Optimization with a linear programming approach was done to maximize or minimize the objective function depending on several input variables (Aprilyanti, 2019). Optimization of the use of production inputs in Pangasius catfish farming was done by Pokdakan Tondo Lestari for one production cycle for 8 months to achieve maximum profit. There were 35 Pangasius catfish aquaculture ponds, which in 
general had an area of $200 \mathrm{~m}^{2}$ and $300 \mathrm{~m}^{2}$ per pond. The total area of the two ponds of $500 \mathrm{~m}^{2}$ produced Pangasius catfish production of $8,010 \mathrm{~kg}$. The production inputs that affected the results of Pangasius catfish culture were thought to be seed, feed and, electricity.

Specifically, the optimization process was done by formulating the objective function and constraint function. The objective function is a function that describes the objectives in the linear programming problems relating to optimal resource management to obtain a maximum profit or minimum cost. Meanwhile, the constraint function is a mathematical presentation of the limits of available capacity which will be allocated optimally (Purwaningsih et al., 2014). The objective function coefficient used the profit contribution per $\mathrm{kg}$ of Pangasius catfish per pond (Table 1). The selling price of Pangasius catfish when harvested with a size of 700 gr per fish was valued at IDR 14,500. Mathematically, the objective function in this study can be written as follows:

$\mathrm{Z}_{\max }=3.887,78 \mathrm{X}_{1}+3.854,62 \mathrm{X}_{2}$

Table 1. Profit per kilogram of Pangasius catfish per pond.

\begin{tabular}{lll}
\hline \multirow{2}{*}{ Data } & Pond Size \\
\cline { 2 - 3 } & $200 \mathrm{~m}^{2}$ & $300 \mathrm{~m}^{2}$ \\
\hline Revenue (IDR) & $46,545,000$ & $69,600,000$ \\
Cost (IDR) & $34,065,213$ & $51,097,819$ \\
Profit (IDR) & $12,479,787$ & $18,502,181$ \\
Pangasius catfish production (kg) & 3,210 & 4,800 \\
Profit/kg & $3,887.78$ & $3,854.62$ \\
\hline
\end{tabular}

Intensive cultivation systems incur higher costs compared to traditional and semi-intensive cultivation systems because intensive cultivation systems use more production inputs. Moreover, one of the characteristics of intensive cultivation systems is high stocking density, which affects the use of other production factors, especially high feeding (Diatin et al., 2008). In this analysis, inputs to produce $1 \mathrm{~kg}$ of Pangasius catfish per pond were on the left-hand side of the constraint function. Meanwhile, the value of the right-hand side (NRK) was the total use of each input during one production cycle. Moreover, the amount of profit with a pool area of $200 \mathrm{~m}^{2}$ was IDR $62,398.94$ per meter, while the amount of profit with a pool area of $300 \mathrm{~m}^{2}$ was IDR 61,673.94 per meter. However, based on the yield (fish weight), the profit obtained between an area of $200 \mathrm{~m}^{2}$ and $300 \mathrm{~m}^{2}$ had a small difference of IDR 33.16.
The stocking density of fish that is not suitable and the use of seeds that are not superior can affect the mortality rate (Wahyudy et al., 2016). The right-hand side (NRK) in the constraint function of Pangasius catfish seeds was obtained from reducing the number of seeds stocked from each pond during one production cycle with a mortality of $5 \%$ during the cultivation process. The number of catfish seeds stocking for 1 year of production was 10,000 , so the mortality of the seeds was 500 to produce $8,010 \mathrm{~kg} /$ cycle. The use of feed for one cycle of Pangasius catfish production was influenced by the stocking density of each cultivation pond. During one year the production for the two ponds was $11,100 \mathrm{~kg}$. One production process for 8 months required 2,104.26 kilowatt $(\mathrm{kW})$ of electricity for pool water replacement. 
Table 2. The use of production inputs to produce $1 \mathrm{~kg}$ of Pangasius catfish and the use of total input during one production cycle.

\begin{tabular}{|c|c|c|c|}
\hline \multirow{2}{*}{ Input } & \multicolumn{2}{|c|}{ Pond Size } & \multirow{2}{*}{ Total Input } \\
\hline & $200 \mathrm{~m}^{2}$ & $300 \mathrm{~m}^{2}$ & \\
\hline Seed (fish) & 1 & 1 & 9,500 \\
\hline Feed $(\mathrm{kg})$ & 1.50 & 1.31 & 11,100 \\
\hline Electricity $(\mathrm{kW})$ & 0.262 & 0.263 & $2,104.26$ \\
\hline
\end{tabular}

The formulation of the constraint function model that can be formed in this study is as follows:

Seed $\quad: X_{1}+X_{2} \leq 9,500$

Feed $\quad: 1.50 \mathrm{X}_{1}+1.31 \mathrm{X}_{2} \leq 11,100$

Electricity : $0.262 \mathrm{X}_{1}+0.263 \mathrm{X}_{2} \leq 2,104.26$

With conditions: $\mathrm{X}_{1} \geq 0 ; \mathrm{X}_{2} \geq 0$

Optimization of production inputs showed that the results of production in factual and optimal conditions had no differences (Table 3). The factual condition of Pangasius catfish production was as much as $8,010 \mathrm{~kg}$, while in the optimal condition the total production was 8,013.05 kg (Figure 1). The difference in the amount of production in factual and optimal conditions was $3.05 \mathrm{~kg}$, indicating that in factual conditions, the Tondo Lestari Pokdakan has planned the cultivation properly, both seed and feed stocking density planning, so the farmers have done the production near-optimal conditions. The production of Pangasius catfish on an area of $200 \mathrm{~m}^{2}$ exceeded the optimal limit of $36.79 \mathrm{~kg}$, while in an area of $300 \mathrm{~m}^{2}$ it had not reached the optimum because it was less than $39.84 \mathrm{~kg}$.

Table 3. Comparison of factual to optimal productions.

\begin{tabular}{lccc}
\hline \multicolumn{1}{c}{ Pond Size } & Factual & Optimal & Difference \\
\hline Production in an area of $200 \mathrm{~m}^{2}$ & 3,210 & $3,173.207$ & -36.79 \\
Production in an area of $300 \mathrm{~m}^{2}$ & 4,800 & $4,839.839$ & 39.84 \\
Total Production (kg) & 8,010 & $8,013.05$ & 3.05 \\
Profit & $30,981,968$ & $30,992,470$ & $10,502.00$ \\
\hline
\end{tabular}

The use of optimal inputs and the dual price value of Pangasius catfish farming (Table 4) showed that the input of seeds in optimal conditions was 8,513 fish, so the availability of seeds was not used as a whole, and there was still a slack/surplus of 1,487 fish from factual conditions. Pokdakan does not need to increase the use of seed input because it produces a dual price value equal to zero, meaning that Pokdakan profits will not increase if additional seed input is added.



Figure 1. Overall production at optimal conditions.

Feed in freshwater fish farming consumes the biggest cost because it can reach $75 \%$ of the total cost required, so the optimal use of feed is necessary so as not 
to suffer losses (Yunaidi et al., 2019). The value of the dual price of feed input was IDR 245.23, which means that if the Pokdakan increases the availability of feed input by $1 \mathrm{~kg}$, the production results will rise and increase the profit of IDR 245.23. Meanwhile, the value of the dual price of electricity input was IDR 13,434.83, which means that if the Pokdakan increases the availability or power of electricity by $1 \mathrm{~kW}$, it will increase the profit of IDR $13.434,83$. Water replacement requires electricity for the availability of dissolved oxygen (DO) in the pond, thereby minimizing the mortality rate. According to Sushanty et al. (2017), cultivators who do not replace the pond water during the maintenance period cause organic matter content to settle in the bottom of the waters so that the water quality decreases and endangers the survival of Pangasius catfish. Water with a low $\mathrm{pH}$ can result in a decrease in growth activity, or it causes the fish to become weak and more susceptible to diseases, usually accompanied by a high mortality rate.

Table 4. The use of optimal inputs and dual price value of Pangasius catfish cultivation.

\begin{tabular}{lllll}
\hline \multicolumn{1}{c}{ Input } & \multicolumn{1}{c}{ Availability } & \multicolumn{1}{c}{$\begin{array}{c}\text { Use in Optimal } \\
\text { Conditions }\end{array}$} & Slack/Surplus & Dual Price (IDR) \\
\hline Seed (fish) & 10.000 & 8.513 & $1.486,953$ & 0 \\
Feed (kg) & 11.100 & 11.100 & 0 & 245,237 \\
Electricity (Kw) & $2.104,258$ & $2.104,258$ & 0 & $13.434,83$ \\
\hline
\end{tabular}

Sensitivity analysis was done to observe changes that occurred in the coefficient of the objective function and the right-hand side of the constraint function and the impact on optimality (Dewi et al., 2014). The confidence interval for all objective function coefficients in Table 5 had a low value, in which the objective function coefficient X1 on the profit per $\mathrm{kg}$ of Pangasius catfish in a $200 \mathrm{~m}^{2}$ pond had a difference between the lower bound and the initial value of IDR 47.82 while the difference between the initial value and the upper bound was of IDR 525.91. Meanwhile, the lower bound on the objective function coefficient $\mathrm{X} 1$ on the profit per $\mathrm{kg}$ of Pangasius catfish in a $300 \mathrm{~m}^{2}$ pond had a difference from the initial value of IDR 459.29 and the difference between the initial value and the upper bound was IDR 48.

Table 5. Sensitivity analysis of the objective function coefficients.

\begin{tabular}{llll}
\hline \multirow{2}{*}{ Variable } & \multirow{2}{*}{ Initial Value } & \multicolumn{2}{l}{ Confidence Interval } \\
\cline { 3 - 4 } & & Lower Bound & Upper Bound \\
\hline Production at $200 \mathrm{~m}^{2}$ & $3,887.78$ & $3,839.964$ & $4,413.688$ \\
Production at $300 \mathrm{~m}^{2}$ & $3,854.62$ & $3,395.328$ & $3,902.619$ \\
\hline
\end{tabular}

The differences between the lower bound of the constrain function coefficients of the seed, feed, and electricity from the initial values (Table 6) were 1,487; 618,72 $\mathrm{kg}$ and 165, $46 \mathrm{~kW}$ respectively. Pangasius catfish seed input had a long confidence interval because the upper bound of the input produced an infinite value (Infinity). If the Pokdakan adds the availability of inputs used, it will not change the value of the dual price and production combination in optimal conditions. However, the upper bound in feed and electricity had a difference from the initial values of $947.28 \mathrm{~kg}$ and 124. 22 kw accordingly. 
Table 6. Analysis of constraint function coefficients.

\begin{tabular}{llll}
\hline \multirow{2}{*}{ Variable } & \multirow{2}{*}{ Initial Value } & \multicolumn{2}{c}{ Confidence Interval } \\
\cline { 3 - 4 } & & Lower Bound & Upper Bound \\
\hline Seed & 9,500 & $8,013.046$ & Infinity \\
Feed & 11,100 & $10,481.28$ & $12,047.28$ \\
Electricity & $2,104.258$ & $1,938.8$ & $2,228.473$ \\
\hline
\end{tabular}

Pokdakan Tondo Lestari as a group guided by the Regency Fisheries Office has always actively updated the development of information and technology in the field of Pangasius catfish farming. The technical guidance was carried out by the Fisheries Office through technical meetings and field assistance by the instructors on Good Aquaculture Practices (CBIB). Coaching on CBIB guided fish cultivators (group members) to comply with the implementation of fish farming principles that are effective, efficient, safe and sustainable. In other words, the Tondo Lestari group has carried out Pangasius catfish farming step by step according to the planning properly to be able to take advantage of production inputs optimally.

\section{CONCLUSION}

The factual condition of the Tondo Lestari fish cultivator group in carrying out Pangasius catfish cultivation is that the group has carried out a good business plan to produce a production, close to optimal conditions with a profit difference of IDR 10,502. The availability of feed and electricity inputs in factual conditions was utilized as a whole, while the use of seed inputs was still excessive. The suggestion that can be given to fish cultivators is not to use Pangasius catfish seeds excessively in a cultivation area of $500 \mathrm{~m}^{2}$ so that it can reduce costs by IDR 446,086 and take advantage of additional feed and electricity inputs to an upper bound of $947.28 \mathrm{~kg}$ and $124.22 \mathrm{~kW}$ to increase profit.

\section{ACKNOWLEDGMENT}

Our gratitude is expressed to the Faculty of Fisheries and Marine Sciences, Brawijaya University; Banyuwangi Fisheries Training and Counseling Center, Pokdakan Tondo Lestari; and the Journal of Aquaculture and Fish Health who has supported the publication of this article.

\section{REFERENCES}

A'yunin, Q., Budianto, Andayani, S. and Pratiwi, D.C., 2020. Analisis kondisi kesehatan ikan patin Pangasius sp. yang terinfeksi bakteri Edwardsiella tarda. Journal of Aquaculture and Fish Health, 9(2), p.164. https://doi. org/10.20473/jafh.v9i2.16192

Akpan, N.P. and Iwok, I.A., 2016. Application of linear programming for optimal use of raw materials in bakery. International Journal of Mathematics and Statistics Invention, 4(8), pp.51-57. https://www.ijmsi. org/Papers/Volume.4.Issue.8/J040 805157.pdf

Aprilyanti, S., 2019. Optimasi keuntungan produksi pada industri kayu PT. Indopal Harapan Murni menggunakan linear programming. Jurnal penelitian dan aplikasi sistem \& teknik industri, 13(1), pp.1-8. https://publikasi.mercubuana.ac.id /index.php/pasti/article/view/547 $6 / 2476$

BPS, 2020. Kabupaten Tulungagung dalam Angka 2020. Badan Pusat Statistik Kabupaten Tulungagung .

Darmawan, J., Tapahari, E. and Pamungkas, W., 2016. Performa benih ikan patin siam Pangasianodon hypophthalmus (Sauvage, 1878) dan pasupati (Pangasius sp.) dengan padat penebaran yang berbeda pada pendederan sistem resirkulasi. Jurnal iktiologi Indonesia, 16(3), pp.243-250. https://doi.org/10.32 491/jii.v16i3.23

Dewi, A.A.S.D.S., Tastrawati, N.K.T. and Sari, K., 2014. Analisis sensitivitas dalam optimalisasi keuntungan 
produksi busana dengan metode simpleks. Jurnal matematika, 4(2), pp.90-101. https://doi.org/10.248 43/JMAT.2014.v04.i02.p48

Diatin, I., Arifianty, S. and Farmayanti, N., 2008. Optimation of Production Input in White Shrimp (Litopenaeus vannamei) Culture: A Case Study in UD. Jasa Hasil Diri at Desa Lamaran Tarung, Kecamatan Cantigi, Kabupaten Indramayu. Jurnal Akuakultur Indonesia, 7(1), pp.1117. https://doi.org/10.19027/jai.7. 39-49

Hasmi, R.A., 2015. Optimasi perencanaan produksi dengan menggunakan metode linear programming pada CV. Aceh Bakery. Jurnal optimalisasi, 1(1), pp.43-56. https:/ /doi.org/10.35308/jopt.v1i1.168

Manunggal, A., Hidayat, R., Mahmudah, S., Sudinno, D. and Kasmawijaya, A., 2018. Kualitas air dan pertumbuhan pembesaran ikan patin dengan teknologi biopori di lahan gambut. Jurnal penyuluhan perikanan dan kelautan, 12(1), pp.11-19. https://doi.org/10.3337 8/jppik.v12i1.97

Meilisza, N., 2009. Budidaya ikan patin di Vietnam: Suatu kajian untuk pengembangan budidaya ikan patin Indonesia. Media akuakultur, 4(1), p.26. https://doi.org/10.15578/ma. 4.1.2009.26-31

Oladejo, N. K., Abolarinwa, A., Salawu, S.O. and Lukman, A.F., 2019. Optimization principle and its' application in optimizing landmark university bakery production using linear programming. International journal of civil engineering and technology (IJCIET), 10(2), pp.183190. https://eprints.lmu.edu.ng/id/ eprint/2139

Poernomo, N., Utomo, N.B.P., and Azwar, Z.I., 2015. The growth and meat quality of Siamese catfish fed different level of protein. Jurnal akuakultur Indonesia, 14(2), pp.104-111. https://doi.org/10.19 027/jai.14.104-111
Purwaningsih, R., Rosyada, Z.F. and Nugrahaeni, V.S., 2014. Model optimasi perikanan budidaya laut (studi kasus Perairan Karimunjawa, Kabupaten Jepara). Jurnal teknik industri, 9(3), pp.157-162. https:// doi.org/10.12777/jati.9.3.157-162

Putra, A.M., Eriyusni and Lesmana, I., 2015. Pertumbuhan ikan patin (Pangasius sp.) yang dipelihara dalam sistem resirkulasi. Jurnal Aquacoastmarine, 3(3), pp.1-12. https://jurnal.usu.ac.id/index.php/ aquacoastmarine/article/view/998 $1 / 4425$

Rumimpunu, A., Andaki, J.A., and Manoppo, V.E.N., 2017. Potensi pengembangan usaha budidaya ikan patin (Pangasius sp.) di Desa Tatelu Kabupaten Minahasa Utara. AKULTURASI: Jurnal Ilmiah Agrobisnis Perikanan, 5(9), pp.713716. https://doi.org/10.35800/akul turasi.5.9.2017.17006

Setyowati, H.A., Nisaa, R.M., Dewantari, O.A., Wicaksono, A., Pahlefi, M.R., Indraputra, A., Christyanti, M.D., Siwi, H.P., Shabrina, N., Wulandari, D., Hapsari, A. and Farda, N.M., 2017. Pemanfaatan SIG dan metode regionalisasi untuk estimasi produksi perikanan darat di Kabupaten Tulungagung, Jawa Timur. Buletin geomaritime, pp.2632. https://online.pubhtml5.com/sf go/ujyq/index.html \#p=2

Sushanty, D.E., Fauziah and Priadi, D.P., 2017. Strategi pengembangan usaha budidaya pembesaran ikan patin (Pangasius sp.) di Kecamatan Gandus Kota Palembang. Jurnal FishtecH, 6(2), pp.126-133. https:// doi.org/10.36706/fishtech.v6i2.584 4

Wahyudy, H.A., Bahri, S. and Tibrani, 2016. Optimasi usaha budidaya ikan air tawar pada Keramba Jaring Apung di waduk PLTA Koto panjang Kabupaten Kampar Provinsi Riau. Jurnal agribisnis, 18(1), pp.11-24. https://doi.org/10.31849/agr.v18i 1.752 
Yahya, W.B., Garba, M.K., Ige, S.O. and Adeyosoye, A.E., 2012. Profit maximization in a product mix company using linear programming. European journal of business and management, 4(17), pp.126-131. https://www.iiste.org/Journals/ind ex.php/EJBM/article/view/3208

Yulisti, M. and Putri, H.M., 2013. Supply chain analysis pengembangan budidaya patin pasupati di Tulung agung, Jawa Timur. Jurnal Kebijakan Sosial Ekonomi Kelautan dan Perikanan, 3(2), pp.165-178. http://dx.doi.org/10.15578/jksekp. v3i2.323

Yunaidi, Rahmanta, A.P. and Wibowo, A., 2019. Aplikasi pakan pelet buatan untuk peningkatan produktivitas budidaya ikan air tawar di Desa Jerukagung Srumbung Magelang. Jurnal Pemberdayaan: Publikasi Hasil Pengabdian kepada Masyarakat, 3(1), pp.45-54. https:/ /doi.org/10.12928/jp.v3i1.621 